Dept. of Theriogenology,

Fac. of Vet. Med. Suez Canal Univ., Head of Dept. Prof. Dr. S.M. Sharawy

\title{
EFFECT OF PROSTAGLANDIN F2 a ON THE EXPULSION OF THE PLACENTA, AND THE INTERVAL FROM BIRTH TO THE FIRST POSTPARTUM ESTRUS IN BUFFALOES*. \\ (With 2 Tables)
}

By

\section{A.S. SHALABY; S.M. SHARAWY; N.H. SALEH and E.A. HASSAN \\ (Received at 23/2/1994)}

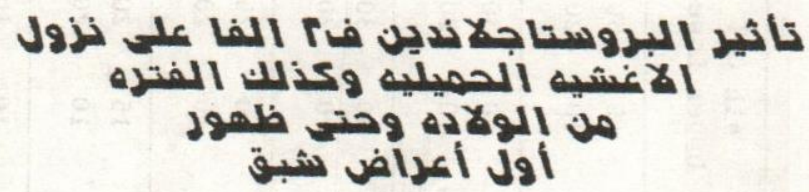

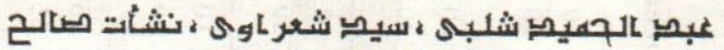

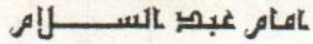

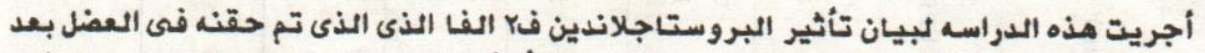

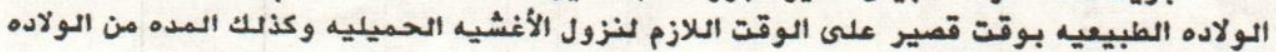

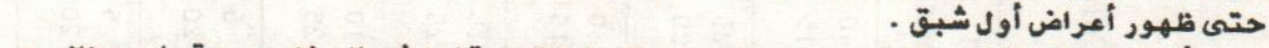

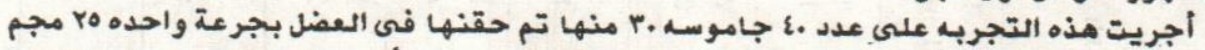

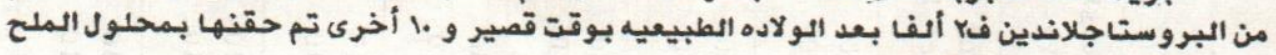

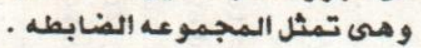

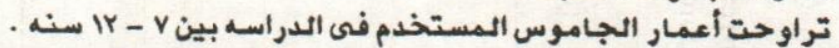

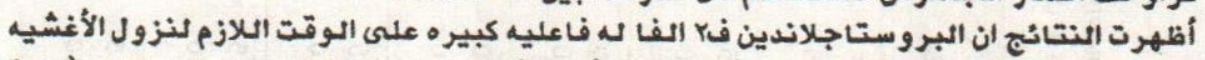

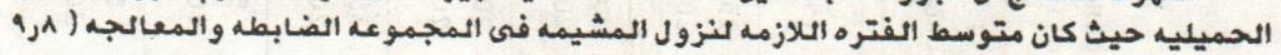

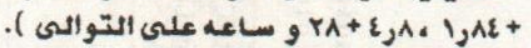

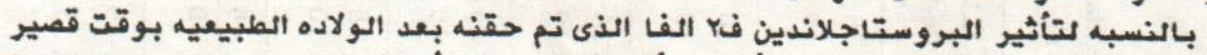

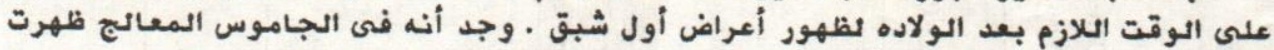

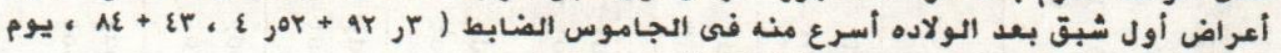

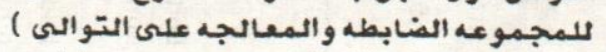

*: This. work is a part of master thesis only supervised by Prof. Dr. Shalaby, A.S. and Prof. Dr. Sharawy, S.M. and Scientifically supported by Dr. Saleh, 


\section{PROSTAGLANDIN F2a, PLACENTA POSTPARTUM ESTRUS \& BUFFALOES}

\section{SUMMARY}

The present study was carried out to investigate the effect of PGF $2 \alpha$ injected shortly after normal parturition in buffaloes on the time needed for placental drop, and the interval from birth to the first postpartum estrus. The experiment was performed on 40 buffalo-cows ( 30 treated+ 10 control), aged from $7-12$ years old at Monofia province. Treated buffaloes received a single i.m. injection of 25 . Omg Lutalyse shortly after calving and the control were injected with saline. PGF $2 \alpha$ shortened significantly $(P<0.05)$ The time elapsed from calving till the spontaneous release of the fetal membranes $(9.8 \pm 1.84$ and $4.8 \pm 0.28 \mathrm{hrs})$ for the control and treated buffaloes respectively. PGF $2 \alpha$ injection early in the postpartum period in buffaloes resulted in a highly significant $(P<0.01)$ decrease in the period elapsed from calving until the first postpartum estrus $(92.3 \pm 4.52$ and $43.0 \pm$ 0.84 days) for the control and treated buffaloes respectively.

Keywords: Prostaglandin F2 $2 \alpha$ placenta, estrus, buffaloes.

\section{INTRODUCTION}

The normal mechanism of fetal membranes drop included the following: The vesseles of the fetal placenta collapsed, the villi shrunken and the uterus still contracted strongly for about $48 \mathrm{hr}$ afterabirth and less vigorously but more frequently, these changes with reducing the amount of the blood circulating in the endometrium reduced the haemorrhage and aided in forcing the fetal membranes into the birth canal (JORDAN, 1952 and GILLETTE and HOLM, 1963). The mean time taken for expulsion of the placenta in multiparous buffaloes was 4.17 \pm 1.21 hrs but buffalo-heifers required an average of $4.56 \pm$ 0.72 hrs. (GUDI et $\underline{\text { al }}$, , 1971) who also reported that, the time needed for expulsion of the placenta during the different months of the year was $4.25,5.09,4.22,4.22,4.59$ and 4.40 hrs in March through August months respectively. They added that early calved buffaloes could expell their placenta in 4.29 hours postpartum while the later ones expelled their placenta in $4.53 \mathrm{hrs}$ after birth. They further added that the time needed for expulsion of the placenta might be affected by the sex of the new born. This time averaged 4.75 and $4.39 \mathrm{hrs}$ after 


\section{A.S. SHALABY et al.}

calving of the female and male fetuses respectively. Finally they found a non significant difference existed in the time of expulsion correlated to the day time of giving birth. HERSCHLER and LAURENCE (1984) reported rapid expulsion of the retained fetal membranes in cows treated. With 1 or $2 \mathrm{mg}$ PGF $2 \alpha$ (fenoprostalene) than in the control animals. $E L-A Z A B$ et al. (1988) found that, the time of retained fetal membranes was reduced when cows were injected with $5 \mathrm{ml}$ of PGF2a (Lutalyse) just after parturition and the mean length of time from parturition to placental release was $5.3 \mathrm{hrs}$ for the control and $4.4 \mathrm{hrs}$ for the PGF2a treated cows. FATTOUH et al. (1990) injected 15 buffalo-cows with $25.0 \mathrm{mg}$ PGF2a (Lutalyse) as a single i.m. dose just after parturition and found that, the mean duration from birth till drop of the fetal membranes was 4. $48 \mathrm{hrs}$ for the PGF2a treated buffaloes compared with $10.0 \mathrm{hrs}$ for the control group.

YOUNG et al. (1984); TINDALL (1984) and YOUNG and ANDERSON (1986) proved that, injection of PGFaa during the postpartum period had exerted a great influence on the interval from calving to first postpartum estrus. EL-SAID (1988) found that the interval from calving to first service in cows was $69.2 \pm$ 19.6 days and $57.8 \pm 14.8$ days in the control and PGFa treated groups respectively.

EL-BAGHDADY et al. (1990) concluded that, in Egyptian buffaloes PGFa significantly shortened the interval from calving to the first service.

The purpose of the present work is to study the effect of PGFa injected shortly after normal parturition in buffalo-cows on the time needed for placental drop and the interval from calving till the first postpartum estrus.

\section{MATERIAL and METHODS}

The animals used in the present study were 40 private buffalo-cows kept at Monofia province. Their age ranged from 7-12 years, gave from 4-7 breeding seasons and were apparently clinically healthy. The nutritional and managemental conditions were not similar. Their newborn calves were allowed to suckle freely their mothers for about 40-60 days postpartum, then were hand milked twice daily.

All the studied buffalo-cows calved normally ( 30 treated + 10 control). The treatment consisted of a single i.m. injection of $25.0 \mathrm{mg}$ Lutalyse within 1/2-1 hour after calving. The control animals (calved normally) were injected with normal saline. The studied animals were injected to calculate the individual time needed for the placental drop. The reproductive

Assiut Vet. Med. J. Yo1. 31 No. 61, Apr 11 1994. 


\section{PROSTAGLANDIN FZa, PLACENTA POSTPARTUM ESTRUS \& BUFFALOES}

tracts were rectally palpated dally allover 9 days postpartum, then once every two days till 21 days and then once every third days after that to asses the colncident ovarian activity. The scheme adopted for examination was the same described by ELFADALY (1978). Vaginoscopy was also done to record the vaginal and cervieal findings. The time from birth till the onset of the first postpartum estrus was recorded for each animal. All the recorded data were statistically analysed using $t$-test to compare between the control and treated buffaloes according to SNEDECOR and COCHRAN (1967).

\section{RESULTS}

As shown in table (1), the mean duration from birth till the drop of the fetal membranes was $9.8 \pm 1.84$ and $4.8 \pm 0.28$ hours for the control and treated buffaloes respectively. It was evident that PGF2a influenced favourably and significantly ( $P<0.05$ ) the time elapsed from calving till the spontaneous release of the fetal membranes. Inspite of injection of PGF $2 \alpha$ after normal parturition in the treated animals, two of them remained with retained fetal membranes and was treated by other preparations.

As shown in table (2), the average length of the interval between calving and the first postpartum estrus in buffalo-cows was $92.3 \pm 4.52$ and $43.0 \pm 0.84$ days for the control and PGF2 $\alpha$ treated buffaloes respectively. The results of statistical analysis revealed that, the interval from birth to the first postpartum estrus was significantly $(P<0.01)$ reduced by injection of PGF2a.

\section{DISCUSSION}

TENNANT (1967) illustrated that in dairy cows the involution of the uterus to its non gravid size and function depended on the contraction of the uterine musculature, loss of placental tissue and fluids and regeneration of the uterine epithelium.

The obtained data (Table 1 ) showed that the mean time needed for placental drop among the control buffaloes was more prolonged ( $9.8 \pm 1.84 \mathrm{hrs})$, than that needed for buffaloes injected with PGF $2 \alpha(4.8 \pm 0.28 \mathrm{hrs})$, the difference was proved in -agreement (1990) who found that injection of $25.0 \mathrm{mg}$ PGF $2 \alpha \mathrm{im}$ after normal parturition led to rapid expulsion of the fetal

Assiut Vet. Med. J. Vol, 31 No, 61, Apri1 1994. 
membranes in the treated group $(4.48 \mathrm{hr}$ ) than the control group $(10.0 \mathrm{hr})$ BRANDER and BYWATER (1982), HERSCHLER and LAWRENCE (1984) and HORTA (1984) found that a rapld expulsion of fetal membranes occurred in cows treated with 1 or $2 \mathrm{mg}$ fenoprostalene.

The obtained results (Table 2) showed that buffalo-cows treated with PGF2 $\alpha$ shortly after normal calving exhibited significant $(P<0.01)$ reduction in the interval between calving and first postpartum estrus in comparison with the untreated ones $(92.3 \pm 4.52$ and $43.0 \pm 0.84$ days for the control and treated buffaloes respectively). These findings were in agreement with those of HAFS et al. (1975); ETHERINGTON (1984); YOUNG et al. (1984) and E1-EKNAWY (1989) who concluded that, the significant reduction in the interval from calving to the first postpartum estrus could be attributed to the influence of PGFi $\alpha$ on the physiological mechanisms involved in quicker return of the ovaries from a relatively quiescent state to a cyclic endocrine activity which extend beyond luteolysis. In conclusion, injection of $25.0 \mathrm{mg}$ Lutalyse as a single i.m dose shortly after normal parturition in buffaloes shortened significantly the time elapsed from calving till the spontaneous release of the fetal membranes. As well as it reduced significantly the interval from birth to the first postpartum estrus.

\section{REFERENCES}

Brander, G.C. and Bywater, R.J. (1982): Veterinary applied pharmacology and therapeutics, 4 - Ed Bailiere tindall. London PP. 197-198.

El-Azab, E.A.; E1-Azab, M.A.; Sharawy, S.M. and Labib, F.M. (1988): Evaluation of various uterotonic single-treatments for prophylaxis of retained placenta in dairy cows. Assiut Vet. Med. J., 20, 156-161.

El-Baghdady, Y. R.M.; FATTOUH, E1.M.; El Eknawy, K.I.; Ayoub, M.M. and Bedeir, L. H. (1990): Effect of oxytocin and/or PGF $2 \alpha$ on breeding efficiency in buffaloes. Egypt. Society for Animal Reproduction and fertility. proc. of Sec Ann. Cong. (January 24-26, 1990) Ismailia, Egypt.

El-Eknawy, K.I. (1989): The role of prostaglandin F2a in monitoring puerperium in buffaloes in Egypt. M. Vet. Sc. Thesis, Cairo Univ.

E1-Fadaly, M. (1978): Studies on the puerperium in buffaloes. M. D. Vet. Thesis, Cairo Univ.

Assiut Vet. Med. J. Vol. 31 No. 61, Apr11 1994. 


\section{PROSTAGLANDIN F2a, PLACENTA POSTPARTUM ESTRUS \& BUFFALOES}

El-Said, G.S. (1988): The postpartum period and the future fertility of cows. M.D. Vet. Thesis, Zagazig Univ.

Etherington, W.G. (1984); Reproductive performance in dairy cows following postpartum treatment with $\mathrm{Gn}$ RH and/or prostaglandin: A field trial. 10 $\mathrm{th}$ Int. Cong. Anim. Reprod. \& A. I. Urbana-Champaign (U.S.A)., 1; 317.

Fat touh, El-S.M.; E1-Baghdady, Y.R.; E1-Eknawy, K.I.; Ayoub, M.M. and Bedeir, L.H. (1990): Effects of prostaglandin F2a and oxytocin on expulsion of the placenta, and uterine involution in Egyptian buffaloes. Egyptian Society for Animal Reproduction and fertility, Proc. Sec. Ann. Cong. (January 24-26, 1990) Ismailia Egypt.

Gillette, D.D. and Holm, L. (1963): prepartum to postpartum uterine and abdominal contractions in cows. Am. J. Physiol., 204, 1115.

Gudi, A.K.; Sohoni, A.D. and Tatke, M.B. (1971): Observation on some aspects of expulsion of placenta in Indian water buffalo (Bublus bubalis). Ind. J. Anim. Sci., $\underline{4}, 145-148$.

Hafs, H.D.; Manns, L.G. and Drew, B. (1975): Onset of estrus after prostaglandin $F_{2 \alpha}$ in cattle. Vet. Rec., 96, 134.

Herschler, R.C. and Lawrence, J.R. (1984): A prostaglandin analogue for therapy of retained placenta. Vet.

Med. Small Anim. Clin., 79, 822-826.

Horta, A.E.M. (1984): A summary of studies concerning the effects of prostaglandins synthesis, inhibition, PGE2 an PGI2 on the expulsion of placenta and myometrial activity in the cow. 10 th Int. Cong. Anim. Reprod \& A. I. Urbanat. Champaign (U.S.A) -, III, 413.

Jordan, W.J. (1952): The puerperium of the cow-A study of uterine motility. J. Comp. Path. and Therap., 62, 54.

Snedecor, G.W. and Cochran, W.G. (1967): Statistical methods. Iowa, 6 th Ed. Iowa state Univ. Press.

Tennant, B. (1967): Uterine involution and ovarian function i: the postpartum cow. A retrospective analysis of 2.3 .5 genital organ examination. Cornell. Vet., 57, 543.

Tindall, J.R. (1984): Increased conception rate in dairy covs: after PGF $2 \alpha$. Vet. Rec., 15, 582.

Young, I.M.; Anderson, D.B. and Plenderleith, R.W. (1984): Increased conception rate in dairy cows after eari? postpartum administration of prostaglandin Faa. Vet. Rec $115,429-431$.

Young, I.M. and Anderson, D.B. .. (1986): First services conception rate in dairy cows treated with dinoprost. tromethamine early postpartum. Vet. Rec., 118, 212-213. 


\section{A.S. SHALABY et al.}

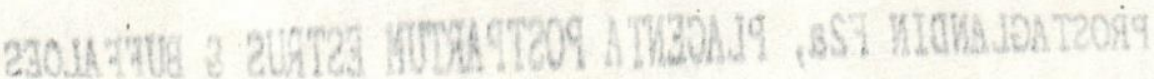

Table (1): The postpartum period (hours) required for the drop of the placenta (Mean \pm S.E)

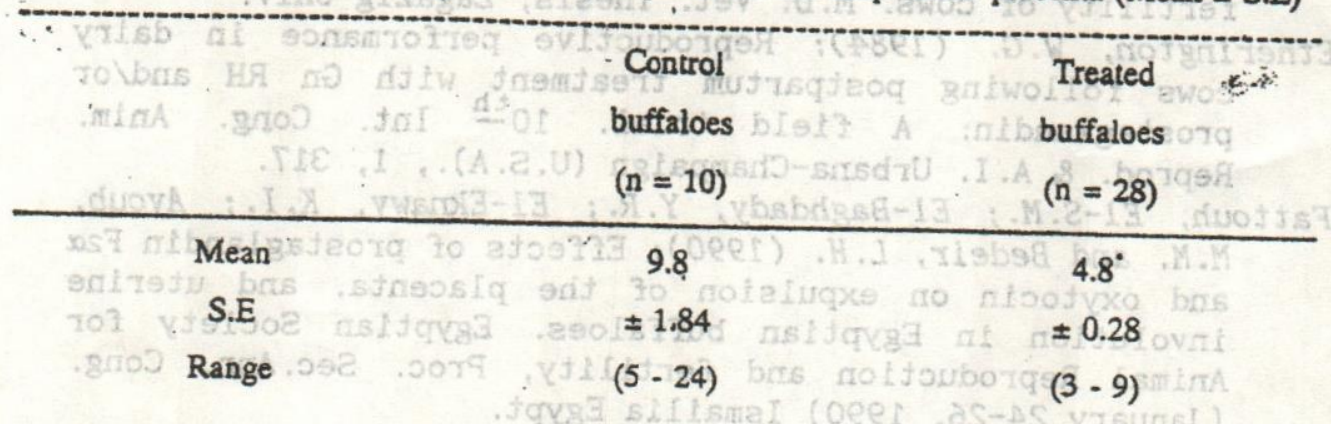

N.B : Two of the treated animals remained with retained fetal membranes.

* Te: Significant difference $(\mathrm{P}<0.05)$.

Table (2): The period (days) from birth to the first postpartum estrus (Mean $=$ S.E).

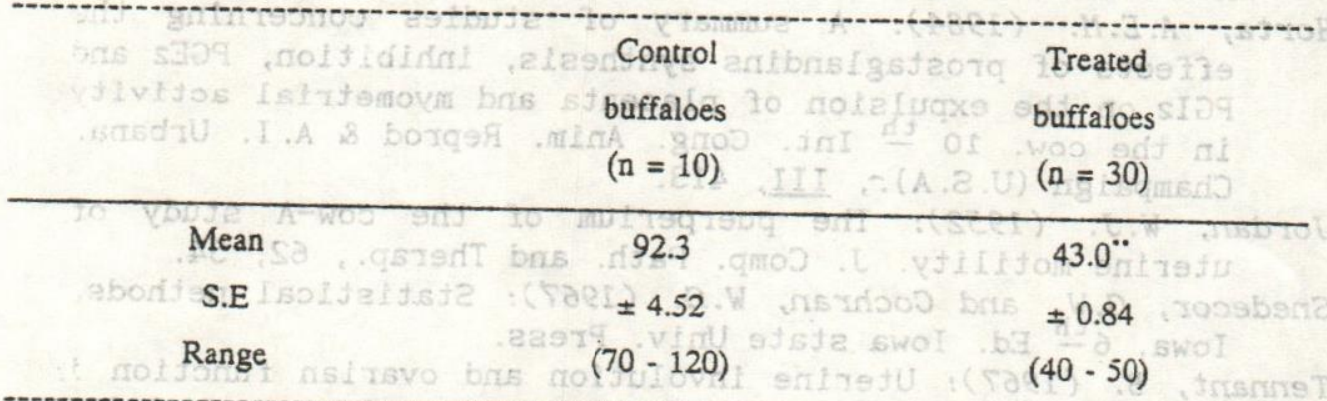

** : Highly significant difference $(P<0.01)$

Assiut Vet. Med. J. Vo1. 31 No. 61, Apr 11 1994. 